Reviu Akuntansi dan Bisnis Indonesia, Vol. 2 No. 1, Hlm: 11-25, Juli 2018

Website: http://journal.umy.ac.id/index.php/rab

\title{
Analisis Kinerja Rumah Sakit Umum Daerah Sleman Berdasarkan Balanced Scorecard Setelah Penerapan Asuransi Badan Penyelenggara Jaminan Sosial Kesehatan
}

\author{
Annisa Ayu Pradibta; Rizal Yaya \\ Program Studi Akuntansi Universitas Muhammadiyah Yogyakarta
}

\section{N F O A R T I K E L}

\section{Kata Kunci:}

Pengukuran Kinerja,

Balanced Scorecard, Badan

Penyelenggara Jaminan

Sosial Kesehatan, Rumah

Sakit Umum Daerah

Sleman

Jenis Artikel:

Penelitian Empiris

Correspondence:

r.vava@umy.ac.id

\begin{abstract}
A B S TRAK
Penelitian ini bertujuan untuk menganalisis Kinerja Rumah Sakit Umum Daerah Sleman berdasarkan Balanced Scorecard setelah penerapan Asuransi Badan Penyelenggara Jaminan Sosial Kesehatan. Pendekatan Balanced Scorecard terdiri dari perspektif keuangan, perspektif pelanggan, perspektif proses bisnis internal dan perspektif pertumbuhan serta pembelajaran. Subjek dalam penelitian ini adalah pasien BPJS Kesehatan baik rawat inap maupun rawat jalan yang telah berobat sebelum dan sesudah diterapkannya penggunaan asuransi BPJS Kesehatan dan karyawan Rumah Sakit Umum Daerah Sleman. Penelitian ini dilakukan dengan metode wawancara, penyebaran kuesioner dan pengambilan data sekunder. Data sekunder yang digunakan pada penelitian ini antara lain realisasi anggaran dan neraca tahun 2013-2016, data pasien tahun 20132017 dan data karyawan tahun 2013-2017. Hasil penelitian ini dilakukan dengan analisis deskriptif. Hasil analisis deskriptif pada penelitian ini dapat disimpulkan sebagai berikut: perspektif keuangan dinilai kurang baik kecuali rasio perputaran aset. Perspektif pelanggan dinilai baik kecuali akuisisi pelanggan. Perspektif proses bisnis internal dinilai baik semua kecuali tingkat rawat jalan dan BTO. Perspektif petumbuhan dan pembelajaran dinilai baik.
\end{abstract}

(C) 2019 RAB. Published by Universitas Muhammadiyah Yogyakarta

\section{PENDAHULUAN}

Kinerja adalah paparan sejauh mana tercapainya suatu pelaksanaan kegiatan, program dan kebijakan pada suatu unit kerja untuk mewujudkan sasaran, tujuan, misi dan visi organisasi. Pengukuran kinerja pada suatu perusahaan bertujuan untuk membandingkan kinerja perusahaan periode lalu dengan periode sekarang, sehingga dapat diketahui apakah kinerja perusahaan tersebut mengalami perbaikan atau penurunan (Sari, 2015).

Sistem pengukuran kinerja sektor publik adalah suatu sistem yang dilakukan dengan tujuan untuk membantu manajemen publik dalam penilaian strategi, baik strategi keuangan maupun strategi non keuangan (Sari, 2015). Selain itu sistem pengukuran kinerja sektor publik juga dijadikan sebagai alat untuk pengendali organisasi. Suatu sistem pengukuran kinerja perusahaan dianggap baik tidak hanya dipandang dari aspek keuangan yang telah melekat pada perusahaan namun juga dipandang dari aspek non keuangan, yaitu pelanggan dan karyawan yang merupakan faktor penting dalam roda perusahaan (Ulum, 2010:275).

Menurut Yasa (2013), organisasi sektor publik cocok menerapkan konsep Balanced Scorecard karena Balanced Scorecard tidak semata-mata hanya ditekankan pada aspek finansial 
namun juga ditekankan pada aspek non finansial. Konsep Balanced Scorecard merupakan suatu konsep dalam pengukuran kinerja yang dapat diterapkan pada rumah sakit, konsep ini diperkenalkan oleh Robert S. Kaplan dan David P. Menurut Sari (2015) saat ini rumah sakit belum menggunakan sistem pengukuran kerja yang komprehensif karena rumah sakit hanya berfokus pada perspektif keuangan, padahal terdapat beberapa perspektif lain yang dapat berpengaruh terhadap pengukuran kinerja. Oleh karena itu, konsep dalam Balanced Scorecard sesuai untuk diaplikasikan pada rumah sakit dalam hal finansial maupun non finansial.

Rumah Sakit Umum Daerah adalah salah satu instansi pemerintah daerah yang bergerak di bidang sektor publik dalam hal jasa kesehatan. Pemerintah Daerah mendirikan Rumah Sakit Umum Daerah (RSUD) untuk pelayanan kepada publik.

Menyadari pentingnya pelayanan kesehatan untuk masyarakat maka pemerintah membuat program kesehatan yaitu salah satunya adalah Jaminan Kesehatan Nasional (JKN) yang diselenggarakan oleh Badan Penyelenggara Jaminan Sosial (BPJS) menurut Peraturan Menteri Kesehatan Republik Indonesia Nomor 71 Tahun 2013 Tentang Pelayanan Kesehatan Pada Jaminan Kesehatan Nasional.

Penelitian ini dilakukan di RSUD Sleman karena RSUD Sleman sebagai jasa pelayanan diharapkan dapat menunjukan kemampuan dan kinerja yang baik. Untuk melakukan fungsi tersebut RSUD Sleman harus meningkatkan kinerjanya. Selain itu Rumah Sakit Umum Daerah Sleman merupakan salah satu rumah sakit yang menerapkan asuransi BPJS Kesehatan dan eumah sakit bertipe $\mathrm{B}$ yang menjadi rujukan dari rumah sakit tipe $\mathrm{C}$.

\section{TINJAUAN LITERATUR DAN PERUMUSAN HIPOTESIS}

\section{Teori Stewardship}

Teori utama yang berhubungan dengan organisasi sektor publik adalah teori stewardship. Teori stewardship menjelaskan situasi dimana manajemen meluruskan tujuan sesuai dengan pemilik, dan manajemen tidak termotivasi oleh tujuan-tujuan individu melainkan akan bertindak sesuai dengan kepentingan pemilik. Akuntansi pada organisasi sektor publik bertujuan untuk memberikan informasi yang diperlukan oleh masyarakat. Dimana pada hal tersebut masyarakat sebagai principal dan pemerintah sebagai agent. Pemerintah adalah pihak yang memiliki kewajiban untuk memberikan informasi yang diperlukan oleh masyarakat atau publik sehingga pemerintah dengan masyarakat memiliki hubungan yang erat.

\section{METODE PENELITIAN}

Obyek penelitian ini dilakukan di Rumah Sakit Umum Daerah (RSUD) Sleman dengan subyek penelitian antara lain wakil direktur rumah sakit, kepala bidang sub keuangan dan akuntansi, kepala bidang sub bagian keperawatan, koordinasi Jamkes Center di RSUD Sleman, karyawan bagian Jamkes Center di RSUD Sleman, karyawan dan pasien BPJS Kesehatan baik rawat inap maupun rawat jalan yang telah berobat sebelum dan sesudah ditetapkannya penggunaan asuransi BPJS Kesehatan.

Penelitian ini menggunakan metode penelitian kuantitatif dan kualitatif dengan analisis deskriptif. Data yang digunakan pada penelitian ini yaitu data primer dan data sekunder, data primer diperoleh dari wawancara dan penyebaran kuesioner sedangkan untuk data sekunder diperoleh dari laporan keuangan tahun 2013-2016, data rumah sakit tahun 2013-2017, data pasien tahun 2013-2017 dan data karyawan tahun 2013-2017.

Pengambilan sampel pada penelitian ini menggunakan purposive sampling. Teknik pengumpulan data pada penelitian ini dilakukan dengan cara wawancara dan penyebaran kuesioner kepada subjek penelitian serta pengambilan data sekunder yang terdiri dari laporan keuangan, data rumah sakit, data peningkatan pasien dan data karyawan. 


\section{Definisi Operasional dan Pengukuran Variabel}

Penelitian ini terdiri dari empat perspektif variabel kinerja dan definisi operasional pada masing-masing perspektif tersebut adalah sebagai berikut:

\section{Perspektif Keuangan}

Beberapa rasio keuangan yang dapat digunakan dalam pengukuran kinerja keuangan, yaitu:

\section{a. Rasio Likuiditas (Current Ratio)}

Rasio likuiditas atau current ratio merupakan suatu indikator mengenai kemampuan rumah sakit dalam membayar segala kewajiban finansial jangka pendek pada saat jatuh tempo dengan menggunakan aset lancar yang tersedia atau kemampuan perusahaan dalam memenuhi kewajiban jangka pendek atau utang lancar. Apabila rasio likuiditas terjadi peningkatan maka dikatakan baik namun apabila terjadi penurunan maka dikatakan kurang baik.

$$
\begin{gathered}
\text { Rasio Likuiditas }=\frac{\text { Aset Lancar }}{\text { Kewajiban Jangka Pendek }} \\
\text { (Sumber Subramanyam, 2008:44) }
\end{gathered}
$$

\section{b. Rasio Profitabilitas}

Rasio Profitabilitas merupakan rasio yang menunjukkan besarnya laba yang diperoleh perusahaan dalam suatu periode tertentu. Dalam pengukuran ini profitabilitas diukur menggunakan ROE (Return On Equity) dan ROA (Return on Assets).

\section{a) Return on Assets (ROA)}

Return on Assets atau ROA digunakan untuk mengetahui seberapa efisien RSUD Sleman dapat dalam mengelola asetnya untuk mengasilkan laba dalam suatu periode. Apabila Return On Assets terjadi peningkatan maka dikatakan baik namun apabila terjadi penurunan dikatakan kurang baik.

$$
\begin{gathered}
\text { ROA }=\frac{\text { Laba/Surplus }}{\text { Total Aset }} \\
\text { (Sumber Subramanyam, 2008:44) }
\end{gathered}
$$

Apabila nilai Return on Assets terjadi penurunan maka dikatakan kurang baik. Namun, apabila terjadi peningkatan maka dikatakan baik.

\section{b) Return on Equity}

Return on Equity digunakan untuk menunjukkan sejauh mana rumah sakit dapat mengelola modal sendiri dengan efektif. Return On Equity dikatakan baik apabila terjadi peningkatan namun apabila terjaadi penurunan maka dikatakan kurang baik.

$$
\mathrm{ROE}=\frac{\text { Laba } / \text { Surplus }}{\text { Ekuitas }}
$$

(Sumber Subramanyam, 2008:44)

\section{c. Rasio Solvabilitas}

Rasio solvabilitas merupakan rasio yang menunjukkan besar aktiva sebuah perusahaan yang didanai menggunakan utang. Rasio ini digunakan untuk mengukur sejauh mana rumah sakit dapat 
membiayai aset dengan menggunakan modal sendiri (ekuitas). Rasio solvabilitas dikatakan baik apabila terjadi peningkatan namun apabila terfjadi penurunan maka dikatakan kurang baik. Apabila rasio solvabilitas terjadi peningkatan maka dikatakan baik namun apabila terjadi penurunan dikatakan kurang baik.

$$
\begin{gathered}
\text { Rasio Modal Sendiri terhadap Total Aset }=\frac{\text { Modal Sendiri }}{\text { Total Aset }} \\
\text { (Sumber Subramanyam, 2008:44) }
\end{gathered}
$$

\section{d. Rasio Aktivitas}

Rasio aktivitas merupakan rasio yang digunakan untuk menganalisis hubungan antara pendapatan operasional dengan investasi dalam bentuk aset, diantaranya periode perputaran piutang dan perputaran total aset.

\section{a) Perputaran Piutang Usaha}

Perputaran piutang usaha digunakan untuk mengetahui kemampuan rumah sakit dalam menagih piutang usaha menjadi kas. Semakin besar perputaran piutang maka rumah sakit dinilai baik dalam mengelola piutangnya, sehingga piutang rumah sakit tidak terlalu besar. Namun sebaliknya, apabila semakin kecil perputaran piutang maka menunjukkan bahwa rumah sakit tidak mampu melakukan penagihan piutangnya, sehingga menimbulkan risiko kemungkinan piutang tidak tertagih.

$$
\begin{gathered}
\text { Perputaran Piutang Usaha }=\frac{\text { Pendapatan }}{\text { Rata-rata Piutang }} \\
\text { (Sumber Subramanyam, 2008:45) }
\end{gathered}
$$

\section{b) Perputaran Total Aset}

Perputaran total aset merupakan rasio yang digunakan untuk mengukur berapa kali dana yang ada di dalam aset yang berputar dalam satu periode.Perputaran total aset yang rendah akan menunjukkan rendahnya tingkat efisiensi dari penggunaan aset dalam menghasilkan pendapatan dan perolehan pendapatan rumah sakit menjadi lambat.

$$
\text { Perputaran Total Aset }=\frac{\text { Pendapatan }}{\text { Rata-rata Total Aset }}
$$

(Sumber Subramanyam, 2008:45)

\section{Perspektif Pelanggan}

\section{a. Kualitas Pelayanan RSUD Sleman Setelah Adanya Penerapan Asuransi BPJS Kesehatan}

Dalam penelitian ini kualitas pelayanan RSUD Sleman setelah adanya penerapan asuransi BPJS Kesehatan diukur melalui penyebaran kuesioner kepada responden baik pasien rawat inap maupun rawat jalan di rumah sakit dengan menggunakan asuransi Badan Penyelenggara Jaminan Sosial (BPJS) Kesehatan.

\section{b. Retensi Pelanggan}

Aspek retensi pelanggan digunakan untuk menunjukkan kinerja rumah sakit dalam kemampuannya mempertahankan hubungannya dengan pelanggan (pasien). Tingkat retensi pelanggan yang tinggi menunjukkan bahwa kinerja rumah sakit dalam mempertahankan hubungan dengan pelanggan (pasien) dinilai baik. 


$$
\begin{gathered}
\text { Retensi Pelanggan } \frac{\text { Total Pasien Lama }}{\text { Jumlah Total Pasien }} \times 100 \% \\
\text { (Sumber Saputri, 2017) }
\end{gathered}
$$

\section{c. Akuisisi Pelanggan}

Akuisisi pelanggan digunakan untuk menunjukkan bahwa seberapa besar rumah sakit dapat meraih pelanggan (pasien) baru. Aspek ini diukur dengan cara membagi total pasien baru dengan jumlah total pasien rumah sakit.

$$
\begin{gathered}
\text { Akuisisi Pelanggan }=\frac{\text { Total Pasien Baru }}{\text { Jumlah Total Pasien }} \times 100 \% \\
\text { (Sumber Saputri, 2017) }
\end{gathered}
$$

\section{Perspektif Proses Bisnis Internal}

Perspektif Proses Bisnis Internal terdiri dari dua proses yaitu proses inovasi dan proses operasi. Dari proses operasi diukur menggunakan tingkat kunjungan rawat jalan dan tingkat kunjungan rawat inap. Sedangkan untuk proses operasi diukur berdasarkan Menteri Kesehatan RI Nomor 828/Menkes/Sk/IX/2008 Tentang Petunjuk Teknis Standar Pelayanan Minimal di bidang Kesehatan Dikabupaten/Kota 2008 antara lain BOR (Bed Occupancy Rate), BTO (Bed Turn Over Rate), TOI (Turn Over Interval), ALOS (Average Length of Stay), GDR (Gross Death Rate), dan NDR (Net Death Rate).

\section{a. Proses Inovasi}

Dalam proses inovasi dilakukan dengan cara meneliti kebutuhan dari pelanggan (pasien) yamg sedang berkembang atau yang belum terlihat dan selanjutnya rumah sakit menciptakan produk baru atau jasa yang memenuhi kebutuhan tersebut.

\section{b. Proses Operasi}

\section{1) Tingkat Kunjungan Rawat Jalan}

Indikator untuk melihat tingkat pemanfaatan rumah sakit dan beban kerja yang ditanggung oleh rumah sakit dilihat dari tingkat kunjungan rawat jalan. Jumlah kenaikan atau penurunan tingkat kunjungan rawat jalan di rumah sakit diukur dengan cara membandingkan selisih jumlah pasien rawat jalan tahun sekarang dibagi dengan jumlah pasien rawat jalan tahun sebelumnya dibagi dengan tahun sebelumnya kali $100 \%$. Apabila nilai rasio likuiditas mengalami penurunan maka dikatakan kurang baik dan dikatakan baik apabila terjadi kenaikan setiap tahunnya.

\section{2) Tingkat Kunjungan Rawat Inap}

Indikator-indikator untuk mengukur tingkat kunjungan rawat inap di RSUD Sleman dapat dilihat diantaranya BOR, ALOS, BTO, TOI, NDR dan GDR. Satuan setiap indikator antara lain BOR (\%), ALOS (hari), BTO (kali), TOI (hari), NDR (permil) dan GDR (Permil).

\section{a) BOR (Bed Accupancy Rate)}

BOR ini digunakan untuk mengukur presentase pemakaian tempat tidur pada satu periode di rumah sakit. Standar ideal BOR yang telah ditetapkan oleh DEPKES RI adalah 60-85\%. Apabila nilai rata-rata BOR tidak sesuai atau dengan standar yag telah ditetapkan maka dikatakan kurang baik namun apabila nila rata-rata BRO sesuai dengan standar yang telah ditetapkan maka dinilai baik. 


$$
\mathrm{BOR}=\frac{\text { Jumlah Hari Perawatan Rumah Sakit }}{\text { (Jumlah tempat tidur } \mathrm{x} \text { jumlah hari dalam satuan waktu }} \times 100 \%
$$

\section{b) ALOS (Average Lenght of Stay)}

ALOS digunakan untuk menggambarkan tingkat efisiensi dan mutu pelayanan di rumah sakit. Standar nilai ALOS yang telah ditetapkan DEPKES RI yaitu 6-9 hari. Apabila nilai rata-rata ALOS tidak sesuai atau dengan standar yag telah ditetapkan maka dikatakan kurang baik namun apabila nila rata-rata ALOS sesuai dengan standar yang telah ditetapkan maka dinilai baik.

$$
\text { ALOS }=\frac{\text { Jumlah hari perawatan pasien keluar }}{\text { Jumlah pasien keluar (hidup+mati) }} \times 100 \%
$$

\section{c) BTO (Bed Turn Over)}

BTO digunakan untuk mengukur frekuensi pemakaian tempat tidur dalam satu periode di rumah sakit, berapa kali tempat tidur tidak digunakan dalam satuan waktu. Standar ideal BOR yang telah ditetapkan oleh DEPKES RI adalah 40-50 kali. Apabila nilai rata-rata BTO tidak sesuai atau dengan standar yag telah ditetapkan maka dikatakan kurang baik namun apabila nila rata-rata BTO sesuai dengan standar yang telah ditetapkan maka dinilai baik.

$$
\mathrm{BTO}=\frac{\text { Jumlah pasien keluar (hidup+mati) }}{\text { Jumlah tempat tidur }} \times 100 \%
$$

\section{d) TOI (Turn Over Interna)}

TOI merupakan indikator yang digunakan untuk mengukur rata-rata hari tempat tidur di rumah sakit tidak diisi sampai tempat tidur tersebut terisi kembali. Standar ideal yang ditetapkan oleh DEPKES RI nilai TOI adalah 1-3 hari. Apabila nilai rata-rata TOI tidak sesuai atau dengan standar yag telah ditetapkan maka dikatakan kurang baik namun apabila nila rata-rata TOI sesuai dengan standar yang telah ditetapkan maka dinilai baik.

$$
\mathrm{TOI}=\frac{\text { (Jumlah tempat tidur } \mathrm{x} \text { Jumlah hari)-Hari perawatan RS }}{\text { Jumlah pasien keluar (hidup+mati) }} \times 100 \%
$$

\section{e) NDR (Net Death Rate)}

NDR merupakan angka kematian 48 jam setelah dirawat untuk setiap 1000 pasien yang keluar. Indikator ini memberikan gambaran mutu pelayanan di rumah sakit. Pada indikator ini semakin kecil nilai NDR, maka semakin baik perawatan dan pencegahan yang dilakukan oleh rumah sakit kepada pasien. Standar ideal yang ditetapkan oleh DEPKES RI pada nilai NDR yaitu $<25$ permil yang artinya nilai NDR kurang dari 25 per 1000 pasien keluar masih ditolelir.

$$
\text { NDR }=\frac{\text { Jumlah pasien mati }>48 \text { jam }}{\text { Jumlah pasien keluar }} \times 100 \%
$$

\section{f) GDR (Gross Death Rate)}

GDR merupakan angka kematian umum untuk setiap 1000 penderita keluar dari rumah sakit. Standar ideal yang ditetapkan oleh DEPKES RI tahun 2005 sebesar < 45 permil. Pada indikator ini semakin kecil nilai NDR, maka semakin baik perawatan dan pencegahan yang dilakukan oleh rumah sakit kepada pasien. Standar ideal yang ditetapkan oleh DEPKES RI pada nilai NDR yaitu < 45 permil yang artinya nilai NDR kurang dari 45 per 1000 pasien keluar masih ditolelir. 


$$
\text { GDR }=\frac{\text { Jumlah pasien mati seluruhnya }}{\text { Jumlah pasien keluar (hidup+mati) }} \times 100 \%
$$

\section{Perspektif Pertumbuhan dan Pembelajaran}

Pada kinerja Rumah Sakit Umum Daerah Sleman dalam perspektif pertumbuhan dan pembelajaran dapat diukur menggunakan tingkat kepuasan karyawan, retensi karyawan, tingkat produktivitas karyawan dan tingkat pelatihan karyawan.

\section{a. Kualitas Kinerja RSUD Sleman Setelah Adanya Penerapan Asuransi BPJS Kesehatan}

Dalam penelitian ini kualitas kinerja RSUD Sleman setelah adanya penerapan asuransi BPJS Kesehatan diukur melalui penyebaran kuesioner kepada karyawan Rumah Sakit Umum Daerah Sleman.

\section{b. Retensi Karyawan}

Retensi karyawan digunakan untuk mengukur kemampuan rumah sakit dalam mempertahankan hubungan yang baik dengan karyawan. Selain itu retensi karyawan diperlukan untuk mempertahankan karyawan yang memiliki keyolatitasan yang tinggi kepada rumah sakit. Retensi yang tinggi menunjukkan kinerja rumah sakit pada aspek ini baik.

$$
\text { Retensi Karyawan }=\frac{\text { Jumlah Karyawan Keluar }}{\begin{array}{l}
\text { Total Jumlah Karyawan } \\
\text { (Sumber Saputri, 2017) }
\end{array} \text { 100\% }}
$$

\section{c. Tingkat Produktivitas Karyawan}

Tingkat produktivitas karyawan digunakan untuk menunjukkan produktivitas karyawan dalam bekerja di rumah sakit pada periode tertentu. Tingkat produktivitas karyawan yang mengalami peningkatan maka digolongkan baik.

$$
\begin{array}{r}
\text { Tingkat Produktivitas Karyawan }=\frac{\text { Pendapatan }}{\text { Jumlah Total Karyawan }} \\
(\text { Sumber Saputri, 2017) }
\end{array}
$$

\section{d. Tingkat Pelatihan Karyawan}

Tingkat pelatihan karyawan digunakan untuk mengukur seberapa banyak RSUD Sleman dalam memberikan pelatihan terhadap karyawannya Pada indikator ini dinilai baik apabila mengalami peningkatan setiap tahunnya.

$$
\text { Tingkat Pelatihan Karyawan }=\frac{\text { Jumlah Karyawan yang Dilatih }}{\text { Jumlah Karyawan }} \times 100 \%
$$

(Sumber Saputri, 2017)

\section{HASIL DAN PEMBAHASAN}

\section{Kinerja Rumah Sakit Umum Daerah Sleman Pada Perspektif Keuangan Setelah Adanya} Penerapan Asuransi BPJS Kesehatan 
a. Rasio Likuiditas

\begin{tabular}{|c|c|c|c|c|c|}
\hline \multirow[t]{2}{*}{ Tahun } & \multirow{2}{*}{$\begin{array}{l}\text { Aset Lancar } \\
\text { (dalam jutaan } \\
\text { rupiah) }\end{array}$} & \multirow{2}{*}{$\begin{array}{l}\text { Utang Lancar } \\
\text { (dalam jutaan } \\
\text { rupiah) }\end{array}$} & \multirow[t]{2}{*}{$\begin{array}{l}\text { Rasio } \\
\text { Likuiditas }\end{array}$} & \multicolumn{2}{|c|}{$\begin{array}{l}\text { Rata-rata Rasio Likuiditas Sebelum dan } \\
\text { Setelah Penerapan BPJS Kesehatan }\end{array}$} \\
\hline & & & & Sebelum & Setelah \\
\hline 2013 & 22.184 .360 & 3.758 .924 & 5,9 & 5,9 & 5,0 \\
\hline 2014 & 31.902 .788 & 3.092.789 & 10,32 & & \\
\hline 2015 & 21.840 .428 & 8.374 .388 & 2,61 & & \\
\hline 2016 & 30.307 .677 & 15.614 .278 & 1,94 & & \\
\hline
\end{tabular}

Sumber : Data Sekunder yang Telah Diolah, 2018

Dari hasil perhitungan rasio likuiditas pada tabel di atas dapat dilihat bahwa pada tahun 2013 nilai rata-rata rasio likuiditas pada RSUD Sleman sebesar 5,9. Sedangkan pada tahun 2014-2016 atau nilai rata-rata rasio likuiditas di RSUD Sleman lebih kecil dari tahun 2013 yaitu sebesar 5,0. Sehingga terjadi penurunan sebesar 0,9. Penurunan nilai rasio likuiditas ini disebabkan oleh adanya jumlah utang dalam negeri sektor perbankan yang tinggi pada tahun 2015 dan 2016. Sehingga dari hasil tersebut rasio likuiditas di RSUD Sleman dinilai "kurang baik".

\section{b. Rasio Profitabilitas}

\section{a) Return On Assets (ROA)}

\begin{tabular}{lllllc}
\hline Tahun & $\begin{array}{l}\text { Surplus/Defisit } \\
\text { (dalam jutaan } \\
\text { rupiah) }\end{array}$ & $\begin{array}{l}\text { Total Aset } \\
\text { (dalam jutaan } \\
\text { rupiah) }\end{array}$ & ROA & \multicolumn{2}{l}{$\begin{array}{l}\text { Rata-rata Return on Assets Sebelum dan } \\
\text { Setelah Penerapan BPJS Kesehatan }\end{array}$} \\
\cline { 3 - 6 } & $(46.026 .703)$ & 118.421 .740 & $-0,39$ & $-0,39$ & Setelah \\
\hline 2013 & $(35.244 .680)$ & 209.374 .594 & $-0,17$ & & -24 \\
2014 & $(95.062 .560)$ & 241.802 .406 & $-0,39$ & & \\
2016 & $(43.012 .928)$ & 277.406 .389 & $-0,16$ & & \\
\hline
\end{tabular}

Sumber : Data Sekunder yang Telah Diolah, 2018

Berdasarkan hasil pengukuran di atas diketahui bahwa nilai rata-rata ROA tahun 2013 sebesar -0,39 sedangkan tahun 2014-2016 rata-rata nilai ROA sebesar -0,24. Terjadi peningkatan sebesar -0,15 namun kedua nilai ROA pada RSUD Sleman tersebut bernilai negatif. Hal tersebut disebabkan oleh saldo yang defisit karena jumlah pendapatan lebih kecil dari jumlah belanja. Hal tersebut dikarenakan RSUD Sleman memakai defisit anggaran pada laporan keuangannya seperti yang digunakan oleh Pemerintah dalam laporan keuangan APBN dan APBD yang memakai defisit anggaran. Anggaran yang defisit tersebut akan ditutup menggunakan SiLPA. Dari hasil pengukuran di atas menunjukkan bahwa Return On Assets (ROA) di RSUD Sleman dinilai "kurang baik".

\section{b) Return On Equity (ROE)}

\begin{tabular}{llllllc}
\hline Tahun & \multicolumn{2}{l}{$\begin{array}{l}\text { Surplus/Defisit } \\
\text { (dalam jutaan }\end{array}$} & $\begin{array}{l}\text { Total Ekuitas } \\
\text { (dalam jutaan }\end{array}$ & ROE & \multicolumn{2}{l}{$\begin{array}{l}\text { Rata-rata Return on Equity Sebelum dan } \\
\text { Setelah Penerapan BPJS Kesehatan }\end{array}$} \\
\cline { 5 - 6 } rupiah) & rupiah) & & Sebelum & $-0,27$ \\
\hline 2013 & $(46.026 .703)$ & 114.662 .815 & $-0,4$ & $-0,4$ & \\
2014 & $(35.244 .680)$ & 206.281 .804 & $-0,17$ & & \\
2015 & $(95.062 .560)$ & 209.686 .643 & $-0,45$ & & \\
2016 & $(43.012 .928)$ & 243.875 .480 & $-0,18$ & & \\
\hline
\end{tabular}

Sumber : Data Sekunder yang Telah Diolah, 2018

Dari hasil pengukuran ROE di atas memperlihatkan bahwa pada tahun 2013 RSUD Sleman memiliki nilai rata-rata ROE sebesar -0,4 sedangkan pada tahun 2014-2016 nilai rata-rata ROE sebesar -0,27. Terjadi peningkatan sebesar -0,13 namun kedua hasil tersebut bernilai negatif. Hal tersebut disebabkan oleh saldo yang defisit karena jumlah pendapatan lebih kecil dari jumlah 
belanja. Hal tersebut dikarenakan RSUD Sleman memakai defisit anggaran pada laporan keuangannya seperti yang digunakan oleh Pemerintah dalam laporan keuangan APBN dan APBD yang memakai defisit anggaran. Anggaran yang defisit tersebut akan ditutup menggunakan SiLPA. Dari hasil pengukuran di atas menunjukkan bahwa Return On Equity ROE) di RSUD Sleman dinilai "kurang baik".

\section{c. Rasio Solvabilitas}

\begin{tabular}{llllll}
\hline Tahun & $\begin{array}{l}\text { Modal Sendiri } \\
\text { (dalam ribuan) }\end{array}$ & $\begin{array}{l}\text { Total } \\
\text { (dalam } \\
\text { ribuan) }\end{array}$ & Aset & $\begin{array}{l}\text { Rasio } \\
\text { Solvabilitas }\end{array}$ & \multicolumn{2}{l}{$\begin{array}{l}\text { Rata-rata Rasio Solvabilitas Sebelum dan } \\
\text { Setelah Penerapan BPJS Kesehatan }\end{array}$} \\
\cline { 3 - 5 } & & & Sebelum & Setelah \\
\hline 2013 & 114.662 .815 & 118.421 .740 & 0,97 & 0,97 \\
2014 & 206.281 .804 & 209.374 .594 & 0,99 & & \\
2015 & 209.686 .643 & 241.802 .406 & 0,87 & \\
2016 & 243.875 .480 & 277.406 .389 & 0,88 & & \\
\hline
\end{tabular}

Sumber : Data Sekunder yang Telah Diolah, 2018

Dari hasil pengukuran di atas dapat dilihat bahwa nilai rata-rata rasio solvabilitas di RSUD Sleman pada tahun 2013 nilainya sebesar 0,97 sedangkan pada tahun 2014-2016 nilai rata-rata rasio solvabilitas sebesar 0,91. Sehingga terjadi penurunan sebesar 0,06. Penurunan tersebut dikarenakan adanya penambahan jumlah aset tetap di rumah sakit. Sehingga dari hasil pengukuran di atas menunjukkan bahwa rasio solvabilitas di RSUD Sleman dinilai "kurang baik".

\section{d. Rasio Aktivitas}

\section{a) Perputaran Piutang Usaha}

\begin{tabular}{llllll}
\hline Tahun & \multicolumn{2}{l}{$\begin{array}{l}\text { Pendapatan } \\
\text { (dalam jutaan } \\
\text { rupiah) }\end{array}$} & $\begin{array}{l}\text { Rata-rata Piutang } \\
\text { (dalam } \\
\text { rupiah) }\end{array}$ & $\begin{array}{l}\text { Perputaran } \\
\text { jutaan }\end{array}$ & $\begin{array}{l}\text { Rata-rata Perputaran Piutang Usaha } \\
\text { Usaha } \\
\text { Sebelum dan Setelah Penerapan BPJS } \\
\text { Kesehatan } \\
\text { Sebelum }\end{array}$ \\
\hline 2013 & 48.237 .167 & 7.373 .757 & 6,54 & 6,54 & Setelah \\
2014 & 48.237 .167 & 9.785 .591 & 4,98 & & \\
2015 & 76.033 .837 & 4.677 .129 & 16,62 & & \\
2016 & 94.851 .109 & 1.796 .653 & 61,55 & & \\
\hline
\end{tabular}

Sumber : Data Sekunder yang Telah Diolah, 2018

Hasil dari pengukuran perputaran piutang usaha tersebut menunjukkan bahwa tahun 2013 nilai rata-rata perputaran piutang usaha yaitu 6,54 sedangkan nilai rata-rata perputaran piutang usaha pada tahun 2014-2016 sebesar 27,72. Sehingga terjadi peningkatan sebesar 21,18. Dari hasil pengukuran di atas menunjukkan bahwa perputaran piutang usaha di RSUD Sleman dinilai " baik".

\section{b) Perputaran Total Aset}

\begin{tabular}{llllll}
\hline Tahun & $\begin{array}{l}\text { Pendapatan (dalam } \\
\text { jutaan rupiah) }\end{array}$ & $\begin{array}{l}\text { Rata-rata Total } \\
\text { Aset } \\
\text { jutaan rupiah) } \\
\text { (dalam }\end{array}$ & $\begin{array}{l}\text { Perputaran Total } \\
\text { Aset }\end{array}$ & $\begin{array}{l}\text { Rata-rata Periode Perputaran } \\
\text { Total Aset Sebelum dan } \\
\text { Setelah Penerapan BPJS } \\
\text { Kesehatan } \\
\text { Bebelum }\end{array}$ \\
\hline 2013 & 48.237 .167 & 95.284 .826 & 0,5 & 0,5 & 0,33 \\
2014 & 48.237 .167 & 163.898 .167 & 0,29 & & \\
2015 & 76.033 .837 & 225.588 .500 & 0,34 & & \\
2016 & 94.851 .109 & 259.604 .398 & 0,37 & & \\
\hline
\end{tabular}

Sumber : Data Sekunder yang Telah Diolah, 2018 
Dari tabel di atas dapat dilihat bahwa rata-rata nilai perputaran total aset RSUD Sleman pada tahun 2013 sebesar 0,5 sedangkan pada tahun 2014-2016 nilai rata-rata perputaran total asetnya sebesar 0,33. Sehingga terjadi penurunan sebesar 0,17. Penurunan tersbut disebabkan karena adanya peningkatan jumlah aset yang tinggi namun tidak dibarengi dengan peningkatan jumlah pendapatan di RSUD Sleman. Dari hasil pengukuran di atas menunjukkan bahwa perputaran total aset di RSUD Sleman dinilai "kurang baik".

\section{Kinerja Rumah Sakit Umum Daerah Sleman Pada Perspektif Pelanggan Setelah Adanya Penerapan Asuransi BPJS Kesehatan}

\section{a. Kualitas Pelayanan RSUD Sleman Setelah Adanya Penerapan Asuransi BPJS Kesehatan}

Berdasarkan analisis deskriptif, maka diperoleh hasil indeks kualitas pelayanan RSUD Sleman setelah adanya penerapan asuransi BPJS Kesehatan pada masing-masing aspek adalah aspek jaminan sebesar 78\%, aspek daya tanggap sebesar $69 \%$, aspek empati sebesar $74 \%$, aspek keandalan sebesar 72\% dan aspek bukti langsung sebesar $82 \%$. Dari hasil pengukuran di atas menunjukkan bahwa kualitas pelayanan RSUD Sleman setelah adanya penerapan asuransi BPJS Kesehatan di RSUD Sleman dinilai " baik".

\section{b. Retensi Pelanggan}

\begin{tabular}{llllll}
\hline Tahun & $\begin{array}{l}\text { Total } \\
\text { Pasien } \\
\text { Lama }\end{array}$ & $\begin{array}{l}\text { Jumlah Total } \\
\text { Pasien }\end{array}$ & $\begin{array}{l}\text { Retensi } \\
\text { Pelanggan }\end{array}$ & $\begin{array}{l}\text { Rata-rata Retensi Pelanggan Sebelum dan } \\
\text { Setelah Penerapan BPJS Kesehatan }\end{array}$ \\
\cline { 5 - 6 } & & & $77 \%$ & $77 \%$ & Sebelum \\
2013 & 94.990 & 122.900 & $80 \%$ & & \\
2014 & 105.884 & 132.020 & $84 \%$ & & \\
2016 & 112.928 & 133.746 & $84 \%$ & & \\
2017 & 129.543 & 150.653 & $86 \%$ & & \\
\hline
\end{tabular}

Sumber : Data Sekunder yang Telah Diolah, 2018

Dari hasil tabel di atas dapat diketahui bahwa nilai rata-rata retensi pelanggan di RSUD Sleman pada tahun 2013 sebesar 77\% sedangkan nilai rata-rata retensi pelanggan pada tahun 20142017 sebesar 84\%. Sehingga terjadi peningkatan sebesar 7\%. Hal ini menunjukkan bahwa RSUD Sleman mampu untuk mempertahankan kepercayaan pelanggan (pasien) terhadap pelayanan yang diberikan oleh rumah sakit dan dinilai "baik".

\section{c. Akuisisi Pelanggan}

\begin{tabular}{lllcll}
\hline Tahun & $\begin{array}{l}\text { Total } \\
\text { Pasien }\end{array}$ & $\begin{array}{l}\text { Jumlah } \\
\text { Pasien }\end{array}$ & Total & $\begin{array}{l}\text { Akuisisi } \\
\text { Pelanggan }\end{array}$ & $\begin{array}{l}\text { Rata-rata Akuisisi Pelanggan Sebelum dan Setelah } \\
\text { Penerapan BPJS Kesehatan }\end{array}$ \\
\cline { 5 - 6 } & & & Sebelum & Setelah \\
\hline 2013 & 27.910 & 122.900 & $22,71 \%$ & $22,71 \%$ & \\
2014 & 26.136 & 132.020 & $19,78 \%$ & & \\
2015 & 20.818 & 133.746 & $15,57 \%$ & & \\
2016 & 21.166 & 150.653 & $14,04 \%$ & & \\
2017 & 20.295 & 148.635 & $13,65 \%$ & & \\
\hline
\end{tabular}

Sumber : Data Sekunder yang Telah Diolah, 2018

Dari hasil tabel di atas menunjukkan bahwa nilai rata-rata akuisisi pelanggan dari tahun 2013 sebesar 22,711\% sedangkan nilai rata-rata akuisisi pelanggan pada tahun 2014-2017 sebesar 16\%, sehingga terjadi penurunan nilai rata-rata akuisisi pelanggan sebesar $6,71 \%$. Penurunan ini disebabkan oleh adanya sistem rujukan berjenjang untuk pasien pengguna asuransi BPJS Kesehatan sehingga RSUD Sleman mengalami penurunan pada jumlah kunjungan pasien baru sehingga 
rumah sakit perlu untuk melakukan evaluasi untuk dapat meningkatkan pelanggan (pasien) baru di rumah sakit. Hal ini menunjukkan bahwa akuisisi pelanggan di RSUD Sleman dinilai "kurang baik".

\section{Perspektif Proses Bisnis Internal}

\section{a. Proses Inovasi}

Proses inovasi dilakukan pihak rumah sakit pada tahun 2013-2017 adalah selalu update dan melengkapi peralatan medis di rumah sakit dengan melihat apa yang dibutuhkan oleh pelanggan. Dapat dilihat di RSUD Sleman peralatan medis sudah lengkap hanya beberapa perlatan saja yang belum tersedia. Selain itu untuk meningkatkan pelayanan jasa yang maksimal, RSUD Sleman saat ini sedang melakukan koordinasi dengan Dinas Kesehatan Provinsi agar pasien yang berada di dekat RSUD Sleman bisa langsung berobat di RSUD Sleman tanpa melalui sistem rujukan berjenjang. Rumah Sakit Umum Daerah Sleman juga melakukan pembangunan gedung baru agar pasien yang berkunjung menjadi nyaman dan rumah sakit menjadi lebih luas. Selain itu fasilitas di rumah sakit dilengkapi agar pengunjung (pasien) juga menjadi nyaman saat berkunjung ke RSUD Sleman.

\section{b. Proses Operasi}

\section{1) Tingkat Kunjungan Rawat Jalan}

\begin{tabular}{lllclc}
\hline Tahun & $\begin{array}{l}\text { Jumlah } \\
\text { Rawat Jalan }\end{array}$ & $\begin{array}{l}\text { Pasien } \\
\text { Kunjungan } \\
\text { Jalan }\end{array}$ & $\begin{array}{r}\text { Tingkat } \\
\text { Rawat }\end{array}$ & $\begin{array}{l}\text { Rata-rata Tingkat Kunjungan Rawat Jalan } \\
\text { Sebelum dan Setelah Penerapan BPJS Kesehatan }\end{array}$ \\
\cline { 5 - 6 } & & $24 \%$ & & Sebelum & Setelah \\
\hline 2013 & 87.837 & $8 \%$ & & \\
2014 & 95.301 & $-3 \%$ & & \\
2015 & 92.532 & $8 \%$ & & & \\
2016 & 99.845 & $1 \%$ & & & \\
2017 & 100.430 & $1 \%$ & &
\end{tabular}

Sumber: Data Sekunder yang Telah Diolah, 2018

Dari data tabel di atas dapat diketahui bahwa nilai rata-rata tingkat kunjungan rawat jalan pada tahun 2013 yaitu sebesar 24\% sedangkan nilai kunjungan rawat jalan rata-rata pada tahun 2014-2017 sebesar 4\% sehingga dapat dilihat bahwa ada penurunan tingkat kunjungan rawat jalan di RSUD Sleman pada tahun 2014-2017 jika dibandingkan dengan tahun 2013. Penurunan tingkat tingkat kunjungan pasien rawat jalan di RSUD Sleman disebabkan adanya prosedur rujukan berjenjang bagi pengguna asuransi Badan Penyelenggara Jaminan Sosial Kesehatan. Hal ini menunjukkan bahwa akuisisi pelanggan di RSUD Sleman dinilai "kurang baik".

\section{2) Tingkat Kunjungan Rawat Inap}

\begin{tabular}{|c|c|c|c|c|c|c|c|c|}
\hline \multirow[t]{2}{*}{ Indikator } & \multicolumn{5}{|c|}{ Tahun } & \multicolumn{2}{|c|}{$\begin{array}{l}\text { Rata-rata Sebelum dan } \\
\text { Setelah Penerapan BPJS } \\
\text { Kesehatan }\end{array}$} & \multirow[t]{2}{*}{$\begin{array}{l}\text { Standar } \\
\text { Ideal }\end{array}$} \\
\hline & 2013 & 2014 & 2015 & 2016 & 2017 & Sebelum & Setelah & \\
\hline BOR & 67,48 & 67,94 & 63,51 & 66,01 & 63,92 & 67,48 & 65,34 & $60-85 \%$ \\
\hline ALOS & 5,14 & 5,13 & 5,03 & 5,06 & 4,31 & 5,14 & 5,0 & 6-9 hari \\
\hline ВTO & 58,67 & 55,91 & 49,79 & 54,51 & 51,68 & 58,67 & 53 & 40-50 kali \\
\hline TOI & 2,06 & 2,09 & 2,68 & 1,65 & 2,55 & 2,06 & 2,24 & 1-3 hari \\
\hline NDR & 13,92 & 20,67 & 22,03 & 19,53 & 19,69 & 13,92 & 20,48 & $<25$ permil \\
\hline GDR & 23,86 & 34,67 & 36,52 & 32,89 & 34,13 & 23,86 & 34,55 & $<45$ permil \\
\hline
\end{tabular}


Dari tabel di atas dapat dilihat bahwa rata-rata indikator tingkat kunjungan rawat inap berada di standar ideal kecuali BTO yang berada di atas standar ideal. Sehingga Tingkat kunjungan rawat jalan dinilai "baik" kecuali pada BTO.

\section{Kinerja Rumah Sakit Pada Perspektif Pertumbuhan dan Pembelajaran Setelah Penerapan Asuransi BPJS Kesehatan}

Adanya

\section{a. Kualitas Kinerja RSUD Sleman Setelah Adanya Penerapan Asuransi BPJS Kesehatan}

Berdasarkan analisis deskriptif, maka diperoleh hasil indeks kualitas kinerja RSUD Sleman setelah adanya penerapan asuransi BPJS Kesehatan pada masing-masing aspek adalah aspek pengambilan keputusan sebesar 73\%, aspek motivasi karyawan sebesar 78\%, aspek pengakuan kinerja sebesar 70\%, aspek memperoleh informasi sebesar $69 \%$ dan aspek kondisi tempat kerja sebesar 70\%. Hal ini menunjukkan rumah sakit mampu memberikan kualitas kinerja kepada karyawan pada aspek keterlibatan dalam pengambilan keputusan, motivasi bekerja, akses untuk memperoleh informasi, pengakuan dan kondisi tempat kerja yang dinilai baik.

\section{b. Retensi Karyawan}

\begin{tabular}{llllll}
\hline Tahun & $\begin{array}{l}\text { Jumlah } \\
\text { Karyawan } \\
\text { Keluar }\end{array}$ & $\begin{array}{l}\text { Total Jumlah } \\
\text { Karyawan }\end{array}$ & $\begin{array}{l}\text { Tingkat Retensi } \\
\text { Karyawan }\end{array}$ & $\begin{array}{l}\text { Rata-rata } \\
\text { Sebelum dan Setelah } \\
\text { BPJS Kesehatan }\end{array}$ & $\begin{array}{c}\text { Retanggan } \\
\text { Penerapan }\end{array}$ \\
\cline { 5 - 6 } & & & & $2 \%$ & \\
\hline 2013 & 10 & 407 & $1 \%$ & & \\
2014 & 3 & 456 & $1 \%$ & & \\
2015 & 4 & 545 & $2 \%$ & & \\
2016 & 9 & 540 & $2 \%$ & & \\
2017 & 13 & 585 & $2 \%$ Setelah & \\
\hline
\end{tabular}

Sumber: Data Sekunder yang Telah Diolah, 2018

Dari data pada tabel di atas dapat dilihat bahwa nilai rata-rata tingkat retensi karyawan tahun 2013 sebesar 2\%, sedangkan pada tahun 2014-2017 nilai rata-rata retensi karyawan sebesar 1\%. Hal ini menunjukkan bahwa terjadi penurunan retensi karyawan pada tahun 2014-2017 dibandingkan tahun 2013. Sehingga hasil dari retensi karyawan di RSUD Sleman dinilai baik.

\section{c. Tingkat Produktivitas Karyawan}

\begin{tabular}{llllll}
\hline Tahun & $\begin{array}{l}\text { Pendapatan } \\
\text { (dalam jutaan } \\
\text { rupiah) }\end{array}$ & $\begin{array}{l}\text { Jumlah } \\
\text { Karyawan }\end{array}$ & $\begin{array}{l}\text { Produktivitas Karyawan } \\
\text { (dalam jutaan rupiah) }\end{array}$ & $\begin{array}{l}\text { Rata-rata } \\
\text { Karyawan Singkat } \begin{array}{l}\text { Produktivitas } \\
\text { Penerapan BPJS Kesehatan } \\
\text { Setan Setelah }\end{array}\end{array}$ \\
\hline 2013 & 48.237 .167 & 407 & 118.519 & Sebelum & Rp 118.519 \\
2014 & 48.237 .167 & 456 & 105.783 & & \\
2015 & 76.033 .837 & 545 & 139.511 & & \\
2016 & 94.851 .109 & 540 & 175.650 & & \\
\hline
\end{tabular}

Sumber: Data Sekunder yang Telah Diolah, 2018

Dari tabel di atas menunjukkan bahwa pada tahun 2013 nilai rata-rata produktivitas karyawan sebesar Rp 118.519 sedangkan pada tahun 2014-2016 nilai rata-rata produktivitas karyawannya sebesar Rp 140.314. Nilai ini menunjukkan bahwa terjadi kenaikan nilai rata-rata produktivitas karyawan tahun 2014-2016 dibandingkan dengan tahun 2013. Sehingga produktivitas karyawan di RSUD Sleman dinilai baik. 


\section{d. Tingkat Pelatihan Karyawan}

\begin{tabular}{lllllc}
\hline Tahun & $\begin{array}{l}\text { Jumlah } \\
\text { Karyawan } \\
\text { yang Dilatih }\end{array}$ & $\begin{array}{l}\text { Jumlah } \\
\text { Karyawan }\end{array}$ & $\begin{array}{l}\text { Pelatihan } \\
\text { Karyawan }\end{array}$ & $\begin{array}{l}\text { Rata-rata Tingkat Pelatihan Karyawan Sebelum } \\
\text { dan Setelah Penerapan BPJS Kesehatan }\end{array}$ \\
\hline 2013 & 383 & 407 & $94,1 \%$ & $94,1 \%$ & Setelah \\
2014 & 449 & 456 & $98,46 \%$ & \\
2015 & 507 & 545 & $93,02 \%$ & \\
2016 & 900 & 540 & $166,66 \%$ & \\
2017 & 595 & 407 & $146,19 \%$ & \\
\hline
\end{tabular}

Sumber: Data Sekunder yang Telah Diolah, 2018

Dari tabel di atas dapat dilihat bahwa pada tahun 2013 nilai rata-rata tingkat pelatihan karyawan sebesar 94,1\%, sedangkan pada tahun 2014-2017 nilai rata-rata tingkat pelatihan karyawan sebesar $126 \%$. Hal ini menunjukkan bahwa terjadi peningkatan tingkat pelatihan karyawan pada tahun 2014-2017 dibandingkan dengan tahun 2013. Sehingga tingkat pelatihan karyawan di RSUD Sleman dinilai baik.

\section{Permasalahan dan Solusi Setelah Adanya Penerapan Asuransi Badan Penyelenggara Jaminan Kesehatan}

Dalam penerapan asuransi BPJS Kesehatan di RSUD terdapat beberapa masalah bagi rumah sakit dan pasien antara lain :

\section{a. Permasalahan}

a) Pasien yang berada di Rumah Sakit Umum Daerah Sleman mengalami penurunan karena adanya prosedur rujukan berjenjang.

b) Pendapatan RSUD Sleman juga menurun karena adanya prosedur rujukan berjenjang.

c) Beberapa pasien kecewa karena tidak dapat secara langsung berobat di RSUD Sleman dengan menggunakan asuransi BPJS Kesehatan setelah adanya rujukan berjenjang.

d) Waktu pendaftaran dan pengambilan obat lama.

\section{b. Solusi bagi permasalahan tersebut}

a) Rumah Sakit Umum Daerah Sleman lebih meningkatkan promosi-promosi ke rumah sakit tipe $\mathrm{C}$ dan $\mathrm{D}$ agar pasien yang tidak bisa ditangani di rumah sakit tersebut dapat langsung dirujuk ke Rumah Sakit Umum Daerah Sleman.

b) Adanya penambahan SDM dan loket dibagian pendaftaran dan pengambilan obat.

c) Adanya petugas BPJS Kesehatan di rumah sakit agar keluhan pasien bisa langsung dijawab oleh pihak dari BPJS Kesehatan dan agar pasien tidak selalu menyalahkan rumah sakit.

d) Adanya sosialisasi tentang BPJS Kesehatan oleh Pemerintah Daerah agar masyarakat mengetahui prosedur-prosedur menggunakan asuransi BPJS Kesehatan.

\section{KESIMPULAN}

Kinerja RSUD Sleman setelah adanya penerapan asuransi BPJS Kesehatan dari perspektif keuangan dinilai kurang baik kecuali rasio aktivitas pada indikator perputaran total aset. Perspektif pelanggan dinilai baik kecuali pada akusisi pelanggan. Perspektif proses bisnis internal dianggap baik kecuali pada tingkat kunjungan rawat jalan dan tingkat kunjungan rawat inap pada indikator BTO. Perspektif pertumbuhan dan pembelajaran dinilai baik. Saran untuk penelitian selanjutnya diharapkan untuk menjelaskan lebih rinci keempat perspektif yang ada di Balanced Scorecard dan mengaitkan perspektif kuangan sampai dengan perspektif pertumbuhan dan pembelajaran sehingga 
dapat menjelaskan apabila terdapat salah satu perspektif yang belum tercapai dengan dikaitkan menggunakan tiga perspektif yang lain.

\section{DAFTAR PUSTAKA}

Al-Najjar, S. M., \& Kalaf, K. H. (2012). Designing a Balanced Scorecard to Measure a Bank's Performance: A Case Study. International journal of business administration. Vol 3 No.4:44.

Areva, D. (2015). Analisis pengukuran Kinerja Dengan Sistem Balanced Scorecard Pada Rumah Sakit Yos Sudarso Padang. JURNAL ECONOMICA: Research of Economic And Economic Education. 1(1), 120-132.

Firdaus, F. F., \& Dewi, A. (2015). Evaluasi Kualitas Pelayanan Terhadap Kepuasan Pasien Rawat Jalan Peserta BPJS di RSUD Panembahan Senopati Bantul. Jurnal Medicoeticolegal dan Manajemen Rumah Sakit. 4 (2).

Hariadi, B. (2002). Akuntansi Manajemen Suatu Sudut Pandang, BPFE-YOGYAKARTA: Yogyakarta.

Kaplan, R.S \& David, P. N. (2000). Balanced Scorecard, Jakarta : Erlangga.

Keputusan Menteri Kesehatan RI Nomor 828/Menkes/Sk/IX/2008 Tentang Petunjuk Teknis Standar Pelayanan Minimal di bidang Kesehatan Dikabupaten/Kota.2008.

Moyang, K. D. (2015). Empat Masalah Paling Dikeluhkan dalam Pelayanan BPJS Kesehatan. https://m.tempo.co/read/news/2015/08/09/173690357/4-masalah-paling-dikeluhkan-dalampelavanan-bpjs-kesehatan. Diakses tanggal 18 Mei 2017 pk 08.00 WIB.

Mulyadi. (2014). Sistem Terpadu Pengelolaan Kinerja Personel Berbasis Balanced Scorecard. UPP STIM YKPN: Yogyakarta.

Peraturan Presiden Republik Indonesia. (2016). Peraturan Presiden Republik Indonesia No. 19 Tahun 2016 Tentang Perubahan Kedua Atas Peraturan Presiden Nomor 12 Tahun 2013 Tentang Jaminan Kesehatan.

Pratolo, S. \& Jatmiko, B. (2017). Akuntansi Manajemen Pemerintah Daerah. LP3M: Yogyakarta.

Putri, M. A. (2017). Analisis Penilaian Kinerja Dengan Menggunakan Metode Balanced Scorecard (Studi Kasus di RSUD Sleman). Skripsi Universitas Sanata Dharma.

Rahimi, H., Kavosi, Z., Shojaei, P., \& Kharazmi, E. (2016). Key performance indicators in hospital based on balanced scorecard model. Journal of Health Management and Informatics. 4 (1), $17-24$.

Rahman, F., dkk. (2015). The Implementation of BPJS Health Program at Public Healh Center Martapura in Banjar Regency. International Refereed Journal of Engineering and Science. $4(4), 26-28$.

Renyowijoyo, M. (2013). Akuntansi Sektor Publik Organisasi Non Laba, Mitra Wacana. Media: Jakarta.

Rondos, K. S. (2016). Analisis Penggunaan Metode Balanced Scorecard Untuk Menilai Kinerja Rumah Sakit Studi Kasus pada Rumah Sakit Umum Daerah Sleman. Skripsi Universitas Sanata Dharma.

Rumengan, D. S., Umboh, J. M. L., \& Kandou, G. D. (2015). Faktor-faktor yang berhubungan dengan pemanfaatan pelayanan kesehatan pada peserta BPJS kesehatan di Puskesmas Paniki Bawah Kecamatan Mapanget Kota Manado. JIKMU. 5(2).

Rumintjap, M. L. (2013). Penerapan Balanced Scorecard sebagai Tolak Ukur Pengukuran Kinerja di RSUD Noongan. Jurnal Riset Ekonomi, Manajemen. Bisnis Dan Akuntansi. 1 (3), 841 959

Saputri, M. D. (2017). Analisis Pengukuran Kinerja Rumah Sakit Dengan Metode Balanced Scorecard (Studi Kasus Pada Rumah Sakit PKU Muhammadiyah Gamping). Skripsi Universitas Muhammadiyah Yogyakarta.

Sari, A. P. (2016). Penerapan Balanced Scorecard Sebagai Alat Pengukuran Kinerja Pada Rumah Sakit Islam Surabaya. Jurnal Ilmu dan Riset Akuntansi. 4(11). 
Sat Pranyoto, V. (2015). Delapan Puluh Persen Pasien RSUD Sleman Pengguna Asuransi. http://jogja.antaranews.com/berita/336483/80-persen-pasien-rsud-sleman-penggunaasuransi. Diakses tanggal 18 Mei 2017 pk 08.20 WIB.

Subramanyam, K.R., \& John J. Wild. (2012). Analisis Laporan Keuangan. Salemba Empat:Jakarta. Sugiyono. 2014. Metode Penelitian Bisnis. Alfabeta: Bandung.

Trihastuti, K. (2012). Analisis Kinerja Perusahaan dengan Metode BSC. Management Analysis Journal, 1 (1).

Ulum, I. (2010). Akuntansi Sektor Publik. UMM Press: Malang.

Undang-undang Republik Indonesia. (2004). Undang-undang No. 40 Tahun 2004 Tentang Sistem Jaminan Sosial Nasional.

Yasa, G. M., \& Suwendra, I. W. (2013). Pengukuran Kinerja Dengan Konsep Balanced Scorecard Pada Rumah Sakit Umum Parama Sidhi Singaraja. JIMAT Jurnal Ilmiah Mahasiswa Akuntansi S1), 1(1). 